\title{
Correction to: Genomic characterization of three novel Basilisk-like phages infecting Bacillus anthracis
}

\author{
J Farlow ${ }^{3,4^{*}}$, D Bolkvadze ${ }^{1}$, L Leshkasheli ${ }^{1}$, I Kusradze ${ }^{1}$, A Kotorashvili², N Kotaria², N Balarjishvili', L Kvachadze', \\ M Nikolich $^{4}$ and M Kutateladze ${ }^{1}$
}

\section{Correction}

Following the publication of this article [1], the authors noted two typographical errors: one in Table 1 with regard to the location of the Basilisk Phage, which was incorrectly captured as "Kutaisis, country of Georgia Utah, USA" but should be "Utah, USA". The second error was an accidental tandem duplication of the following paragraph on page 14:

"Full-length sequences of the putative BLP endolysins display closer overall homology to Bacillus group members than cultured phages. We speculate this pattern may reflect gene acquisition from host Firmicutes. Other authors have previously speculated that instances of strong homology observed between $B$. cereus phage MurNAc-LAA endolysins and host autolysins may reflect horizontal transfer between Bacillus phages and various B. cereus group hosts [30]. The molecular diversity of the BLP lysins and their homologs is exhibited primarily by the presence or absence of the C-terminal amidase_02C domain. Consistent with previous data on lysPBC4 [9] the N-terminal amidase_3 domain of the BLPs show greater conservation among their homologs than the C-terminal amidase_02C domain and linker re- gion that are absent in most phage endolysin homologs."

\footnotetext{
Author details

'George Eliava Institute for Bacteriophages, Microbiology and Virology, Tbilisi, Georgia. ${ }^{2}$ Lugar Center for Public Health Research at National Center for Disease Contro, Tbilisi, Georgia. ${ }^{3}$ Farlow Scientific Consulting Company, LLC, Lewiston, UT, USA. ${ }^{4}$ Department of Bacteriophage Therapeutics, Bacterial Diseases Branch, Walter Reed Army Institute of Research, Silver Spring, Silver Spring, MD, USA.
}

Received: 21 September 2018 Accepted: 21 September 2018 Published online: 27 September 2018

\author{
Reference \\ 1. Farlow, et al. BMC Genomics. 2018;19(685). https://doi.org/10.1186/s12864- \\ 018-5056-4.
}

\footnotetext{
* Correspondence: farlowscience@gmail.com; jason.e.farlow.ctr@mail.mil

${ }^{3}$ Farlow Scientific Consulting Company, LLC, Lewiston, UT, USA

${ }^{4}$ Department of Bacteriophage Therapeutics, Bacterial Diseases Branch,

Walter Reed Army Institute of Research, Silver Spring, Silver Spring, MD, USA
}

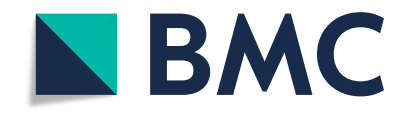

(c) The Author(s). 2018 Open Access This article is distributed under the terms of the Creative Commons Attribution 4.0 International License (http://creativecommons.org/licenses/by/4.0/), which permits unrestricted use, distribution, and reproduction in any medium, provided you give appropriate credit to the original author(s) and the source, provide a link to the Creative Commons license, and indicate if changes were made. The Creative Commons Public Domain Dedication waiver (http://creativecommons.org/publicdomain/zero/1.0/) applies to the data made available in this article, unless otherwise stated. 